\title{
Performansi Algoritma Proportional Integral Controller Enhanced (PIE) dan DropTail Pada Layanan VoIP
}

\author{
Siti Amatullah Karimah ${ }^{\# 1}$, Aji Gautama Putrada ${ }^{* 2}$, Fadli Rianda ${ }^{\# 3}$ \\ \# Fakultas Informatika, Universitas Telkom \\ Jl. Telekomunikasi No. 01, Terusan Buah Batu, Bandung 40257 \\ ${ }^{1}$ karimahsiti@telkomuniversity.ac.id, 22ajigps@telkomuniversity.ac.id \\ ${ }^{3}$ sirvaith@student.telkomuniversity.ac.id
}

\begin{abstract}
Voice over Internet Protocol (VoIP) is a communication technology that uses the Internet to conduct long-distance communication. VoIP develops along with the development of mobile devices and the Internet. This massive use of the Internet will cause the possibility of bufferbloat. Bufferbloat is an event where a large buffer will always be fully loaded and result in the length of the queue in the buffer. If this is allowed, the transmission delay will be high. One method that can be used to overcome this problem is Active Queue Management (AQM). This study presents the performance of 2 AQM pieces namely Proportional Integral controller Enhanced (PIE) and DropTail for VoIP services. Quality measurement was assessed using the calculation of Mean Opinion Score (MOS). Assessment is divided into two, namely subjective and objective. Subjectively, the value of MOS is obtained by listening to the sound quality directly. Objectively, the MOS value is obtained by R-Factor calculation. The results of the comparison of the value of Mean Opinion Score (MOS) both subjectively and objectively indicate that the quality of VoIP with the PIE algorithm is better than Droptail which is $30 \%$ and $20 \%$ better on subjective and objective judgments. Both MOS are taken from the smallest traffic shaping, which is $70 \mathrm{Kbps}$, which is the worst case of the tested scenario.
\end{abstract}

Keywords: MOS, VoIP, AQM, Proportional Integral Controller Enhanced, DropTail

Abstrak

Voice over Internet Protocol (VoIP) merupakan teknologi komunikasi yang memanfaatkan Internet untuk melakukan komunikasi jarak jauh. VoIP berkembang seiring dengan berkembangnya mobile device dan Internet. Penggunaan jaringan Internet secara masif ini akan menimbulkan kemungkinan terjadinya bufferbloat. Bufferbloat merupakan kejadian dimana buffer yang berukuran besar akan selalu terisi penuh dan berakibat pada panjangnya antrian dalam buffer. Jika hal ini dibiarkan, maka delay transmisi menjadi tinggi. Salah satu metode yang dapat digunakan untuk mengatasi masalah ini adalah Active Queue Management (AQM). Penelitian ini menyajikan performansi 2 buah AQM yakni Proportional Integral controller Enhanced (PIE) dan DropTail untuk layanan VoIP. Pengukuran kualitas dinilai menggunakan perhitungan Mean Opinion Score (MOS). Penilaian terbagi menjadi dua yaitu subjektif dan objektif. Secara subjektif, nilai MOS didapatkan dengan mendengarkan langsung kualitas suara. Secara Objektif, nilai MOS didapatkan dengan perhitungan R-Factor. Hasil perbandingan nilai Mean Opinion Score (MOS) baik secara subjektif maupun objektif menunjukan bahwa kualitas VoIP dengan algoritma PIE lebih baik daripada Droptail yakni 30\% dan 20\% lebih baik pada penilaian subjektif dan objektif. Kedua MOS ini diambil dari traffic shaping terkecil yakni $70 \mathrm{Kbps}$ yang merupakan worst case dari skenario yang diujikan.

Kata Kunci: MOS, VoIP, AQM, Proportional Integral Controller Enhanced, DropTail 
Siti A. Karimah et.al.

\section{PENDAhUluAN}

$\mathbf{T}$ EKNOLOGI saat ini menjadi salah satu hal yang melekat dan tak terpisahkan dari kehidupan masyarakat. Salah satunya adalah Internet. Berbagai macam jenis data membanjiri Internet, bukan hanya data berupa teks, namun juga data multimedia yang bersifat real time dan membutuhkan penggaransian performansi, agar layanan dapat diterima dengan baik oleh pengguna. Salah satu layanan multimedia yang saat ini berkembang adalah layanan Voice over Internet Protocol atau yang biasa disebut VoIP. Pembanjiran data di Internet secara langsung akan mempengaruhi kualitas layanan VoIP. Teknologi ini memungkinkan pengguna untuk melakukan panggilan telepon melalui jaringan IP [2]. Aplikasi VoIP ini bersifat realtime sehingga membutuhkan jitter dan delay yang rendah. Pada saat ini sebagian besar penyedia layanan VoIP di internet lebih memilih protokol UDP dibanding TCP sebagai protokol transport. Tidak adanya congestion control pada UDP mengakibatkan delay dan jitter pada receiver menjadi besar. Hal ini menyebabkan masalah pada jaringan dan akan berdampak langsung pada pengguna layanan VoIP[3].

Paket data VoIP yang dirancang untuk mengalir secepat mungkin membuat antrian pada buffer cepat penuh. Buffer diperlukan untuk menampung sementara arus paket yang cepat. Buffer yang terus dialiri arus paket, lama-lama akan menjadi penuh dan mengakibatkan waktu penanganan paket menjadi sangat lama. Jika hal ini dibiarkan terus-menerus, akan menyebabkan latency yang tinggi, dimana fenomena ini biasa disebut bufferbloat. Bufferbloat merupakan salah satu kondisi buffer dengan ukuran besar dan cenderung selalu penuh dan menyebabkan antrian panjang di dalam buffer, jika hal ini dibiarkan maka akan menyebabkan jeda transmisi yang tinggi [4].

Solusi dari fenomena bufferbloat adalah dengan menggunakan Active Queue Management (AQM) yang berguna untuk memantau dan mengelola queue. Sebagian besar router saat ini menggunakan metode first infirst out (FIFO) yang biasanya disebut Droptail sebagai disiplin antriannya. Ada banyak macam Active Queue Management (AQM), seperti CoDel, PIE, RED, HRED, dsb. Proportional Integral Controller Enhanced (PIE) merupakan salah satu jenis AQM yang memiliki kualitas baik dalam mengangani koneksi real-time.

Proportional Integral Controller Enhanced (PIE) merupakan salah satu algoritma Active Queue Management (AQM) dengan tujuan utama desainnya adalah melakukan kontrol terhadap latency agar tetap rendah, utilitas link yang tinggi, implementasi yang mudah, kestabilan terjamin dan respon yang cepat [5]. Pada penelitian ini akan meninjau kinerja PIE dalam mengatasi layanan real-time dengan mengimplementasikannya pada jaringan VoIP.

Pada penelitian sebelumnya dilakukan perbandingan kualitas layanan menggunakan algoritma CoDel, dimana pada penelitian sebelumnya, CoDel memiliki beberapa kekurangan diantaranya drop behavior yang selalu berubah setiap waktu yang akan berimbas pada underutilization. Algoritma PIE yang digunakan akan menyelesaikan permasalahan drop behavior ini dimana PIE mengadopsi kekuatan algoritma RED, dimana proses dropping dilakukan sebelum terjadinya congestion, sehingga akan meningkatkan performansi dan kualitas layanan.

\section{DASAR TEORI}

\section{A. Voice Over Internet Protocol (VoIP)}

Voice over Internet Protocol (VoIP) adalah integrasi dari layanan telepon konvensional dengan semakin bertambahnya jumlah aplikasi berbasis IP (IP-based applications). Teknologi ini merupakan salah satu teknologi yang sangat berkembang dan banyak didukung oleh penyedia layanan telekomunikasi[12]. Layanan ini memungkinkan pengguna membuat panggilan telepon melalui koneksi Intenet.

VoIP bekerja dengan cara mengirimkan sinyal digital. Sebelum proses transmisi dilakukan, pertama-tama dilakukan konversi data berupa sinyal analog menjadi sinyal digital menggunakan ADC (Analog to Digital 
Converter). Setelah itu data berupa sinyal digital ini ditransmisikan ke sumber tujuan, untuk kemudian di konversi kembali menjadi sinyal analog di tujuan menggunakan DAC (Digital to Analog Converter)[13].

\section{B. Active Queue Management (AQM)}

Active Queue Management adalah suatu metode dimana perangkat jaringan dapat mengontrol panjang antrian atau lama waktu paket yang diperbolehkan untuk tetap berada di buffer pada perangkat. Active Queue Management (AQM) merupakan salah satu cara untuk menangani kondisi buffer dengan ukuran besar yang cenderung selalu penuh dan menyebabkan antrian panjang di dalam buffer yang dapat menyebabkan jeda tranmisi yang tinggi jika terjadi terus-menerus atau biasa disebut dengan bufferbloat [2].

\section{Proportional Integral Controller Enhanced (PIE)}

Proportional Integral Controller Enhanced atau yang lebih dikenal dengan PIE merupakan gabungan dari kelebihan algoritma RED dan CoDel yakni mudah diimplementasikan seperti RED dan tetap mengontrol latency seperti CoDel[10].

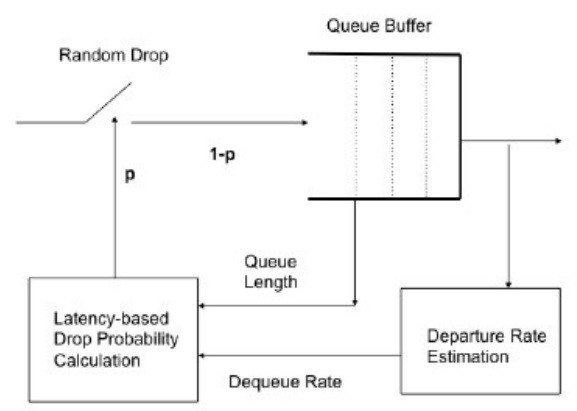

GAMBAR 1. SKEMA PIE

\section{a) Random Dropping}

Seperti pada kebanyakan AQM, PIE akan melakukan drop paket secara random, bergantung pada drop probability $(p)$, dimana $p$ didapatkan dari komponen drop probability calculation.

\section{b) Drop Probability Calculation}

Berikut adalah drop probability pada algoritma PIE :

- $\quad$ Estimasi delay pada queue

$$
\operatorname{cur}_{\text {del }}=\frac{\text { qlen }}{\text { avg }_{\text {drate }}}
$$

- $\quad$ Menghitung nilai $p$

$$
p=p+a *\left(c_{u r} r_{d e l}-r e f_{d e l}\right)+\beta *\left(\text { cure }_{d e l}-o l d_{d e l}\right)
$$

- $\quad$ Update delay

$$
o_{\text {old }}=\text { cur_del }
$$


Siti A. Karimah et.al.

\section{c) Departure Rate Estimation}

Pada saat paket dikirim :

- $\quad$ Memutuskan untuk berada dalam siklus pengukuran, jika :

$$
\text { qlen }>d q_{\text {treshold }}
$$

- $\quad$ Apabila nilai di atas True, perbarui hitungan keberangkatan $d q_{-}$count :

$$
d q_{\text {count }}=d q_{\text {count }}+d q_{\text {pktzise }}
$$

- $\quad$ Perbarui departure rate $d q_{\text {count }}>d q_{-}$treshold dan reset penghitungan ;

$$
\begin{aligned}
& d q_{\text {int }}=\text { now }- \text { start }: \\
& d q_{\text {rate }}=\frac{d q_{\text {count }}}{d q_{\text {int }}} \\
& \text { avg } g_{\text {drate }}=(1-\varepsilon) * a v g_{\text {drate }}+\varepsilon * d q_{\text {rate }} \\
& \text { start }=\text { now } \\
& d q_{\text {count }}=0
\end{aligned}
$$

\section{d) Handling Bursts}

Tiga komponen di atas adalah komponen dasar dari algoritma PIE. Berikut ini adalah perhitungan burst allowance dari algoritma PIE,

Pada saat paket diterima :

- If burst_allow $>0$

$$
\text { Enque packet bypassing rabdin drop; }
$$

Pada saat $d q_{\text {rate }}$ diperbarui

- Update burst allowance:

- If $p=0$; and both cur $_{\text {del }}$ and old del less than ref $f_{\text {del }} / 2$, reset burst allow, $_{\text {, }}$,

burst $_{\text {allow }}=$ max_burst; $_{\text {; }}$

Jadi semua komponen di atas adalah komponen penting pada skema algoritma PIE untuk mengontrol latency tetap rendah dan untuk menjaga tidak terjadinya bufferbloat. Pada Linux (dengan kernel 3.5 atau di atasnya), modul kernel PIE dapat diterapkan menggunakan tc atau traffic control.

\section{Droptail}

Droptail adalah algoritma AQM yang sangat sederhana dan merupakan konfigurasi default pada kebanyakan router. AQM ini tidak membedakan traffic dari sumber yang berbeda. Selama antrian terisi, paket berikutnya akan di drop. Dengan kata lain, AQM ini akan melakukan drop ekor (tail) dari urutan paket.

Ide dari AQM Droptail ini adalah paket pertama yang tiba di router adalah paket pertama yang akan dikirimkan. Mengingat bahwa jumlah ruang buffer yang terbatas pada setiap router, jika sebuah paket tiba dan antrian penuh, maka router akan membuang paket tersebut. Hal ini dilakukan tanpa mempedulikan jenis aliran atau seberapa pentingnya paket tersebut. Kinerja sistem antrian dengan karakteristik M/M/1 tergantung pada parameter berikut:
a. Tingkat kedatangan paket.
b. Ukuran paket.
c. Kapasitas layanan. 
Antrian M/M/1 umumnya digambarkan oleh proses Poisson yang mengatur kedatangan paket ke buffer terbatas. Ketika sebuah paket mencapai kepala buffer, diproses oleh server dan dikirim ke tujuannya [14].

\section{PERANCANGAN SiSTEM}

\section{A. Topologi Jaringan}

Pada penelitian ini dibangun sistem yang dapat melakukan perhitungan nilai Mean Opinion Score (MOS) dan $R$-Factor pada jaringan VoIP. Sistem ini dibangun menggunakan VMware Workstation dengan beberapa node yaitu client 1 , client 2, router, dan server Asterisk dimana client 1, router, server Asterisk berada pada 1 Personal Computer (PC) dan client 2 pada Laptop.

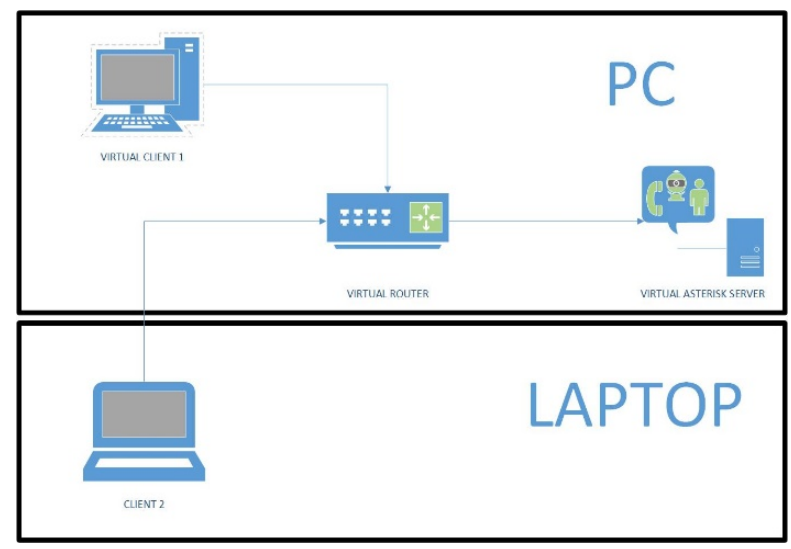

GAMBAR 2. TOPOLOGI

Pada interface router untuk client 1 dan client 2, bandwidth akan disesuaikan sampai mendapatkan angka yang menunjukan perbedaan yang jelas antara menggunaka AQM PIE dan Droptail. Active Queue Management sendiri diatur pada router. Pada linux, modul kernel PIE dapat diterapkan menggunakan $t c$ atau traffic control.

\section{a) Client}

Client berupa komputer virtual yang menggunakan operating system Linux yang di install software softphone Zoiper.

b) Server Asterisk

Asterisk dimplementasikan pada secara virtual menggunakan operating system Linux.

\section{c) Router}

Router menggunakan Linux pada sebuah komputer virtual.

\section{B. Skenario Pengujian}

Skenario yang digunakan dalam penelitian ini yakni router terhubung dengan client dan server asterisk. Pengujian dilakukan menggunakan traffic shaping dengan mengatur bandwidth pada setiap interface router yang terhubung ke client1 dan client2. Pengaturan bandwidth dilakukan sedemikian rupa agar terjadi bottleneck.

\section{a) Kondisi bottleneck 90kbps dan 90kbps}

Skenario ini di implementasikan pada router yang terhubung pada client 1 dan client 2 . Fungsi bottleneck di atur pada setiap interface yang terlibat antara client dan router. Interface yang menghubungkan router dengan client1 diatur dengan kecepatan $90 \mathrm{kbps}$ dan interface yang menghubungkan router dengan 
Siti A. Karimah et.al.

client2 diatur dengan kecepatan 90kbps. Percobaan panggilan VoIP dilakukan dari client1 ke client2 dengan mengimplementasikan algoritma DropTail dan PIE pada sisi router.

\section{b) Kondisi bottleneck 80kbps dan 80kbps}

Skenario ini di implementasikan pada router yang terhubung pada client 1 dan client2. Fungsi bottleneck di atur pada setiap interface yang terlibat antara client dan router. Interface yang menghubungkan router dengan client1 diatur dengan kecepatan $80 \mathrm{kbps}$ dan interface yang menghubungkan router dengan client2 diatur dengan kecepatan $80 \mathrm{kbps}$. Percobaan panggilan VoIP dilakukan dari client1 ke client2 dengan mengimplementasikan algoritma DropTail dan PIE pada sisi router.

\section{c) Kondisi bottleneck $75 \mathrm{kbps}$ dan $75 \mathrm{kbps}$}

Skenario ini di implementasikan pada router yang terhubung pada client 1 dan client 2 . Fungsi bottleneck di atur pada setiap interface yang terlibat antara client dan router. Interface yang menghubungkan router dengan client1 diatur dengan kecepatan $75 \mathrm{kbps}$ dan interface yang menghubungkan router dengan client2 diatur dengan kecepatan $75 \mathrm{kbps}$. Percobaan panggilan VoIP dilakukan dari client1 ke client2 dengan mengimplementasikan algoritma DropTail dan PIE pada sisi router.

\section{Parameter Pengujian}

Terdapat tiga parameter uji yang digunakan dalam menganalisa mekanisme Proportional Integral Controller Enhanced (PIE) dan DropTail

a. Delay

Delay adalah waktu yang dibutuhkan paket data untuk ditransmisikan dari pengirim ke penerima. Kualitas delay dikatakan baik apabila waktu tunda yang terjadi hanya sekitar 0 - $150 \mathrm{~ms}$ [2][3]. Rata rata delay dapat dihitung menggunakan persamaan (6).

$$
\text { rata }- \text { rata delay }=\frac{\text { total delay }}{\text { total paket diterima }}
$$

\section{b. Throughput}

Throughput merupakan kecepatan transfer data efektif, diukur dalam satuan bps (bit per second). Throughput adalah jumlah total kedatangan paket yang sukses, diambil dari sisi tujuan selama interval waktu tertentu dibagi oleh durasi interval waktu transmisi [3]. Throughput dapat dihitung menggunakan persamaan (7).

$$
\text { throughput }=\frac{\text { paket data diterima }}{\text { lama pengamatan }}
$$

\section{c. Packet Loss}

Packet Loss merupakan jumlah paket yang hilang dalam suatu pengiriman paket data ketika di transmisiskan di jaringan. Packet loss terjadi oleh beberapa sebab diantaranya noise, collision dan congestion yang disebabkan oleh ketidakmampuan buffer menampung antrian paket pada jaringan. Packet Loss pada VoIP dikatan baik apabila berkisar antara $0 \mathrm{~s} / \mathrm{d} 0.5 \%$ dari pengiriman data [2][19]. Packet loss dapat dihitung menggunakan persamaan (8).

$$
\text { packet loss }=\frac{(\text { paket data dikirim-paket data diterima }) \times 100 \%}{\text { paket data yang dikirim }}
$$




\section{d. R-factor}

$R$-Factor merupakan hasil pengukuran dari E-Model yang dipergunakan untuk memprediksi nilai dari Mean Opinion Score (MOS) secara objektif. E-Model itu sendiri merupakan pengukuran secara objektif pada jaringan telekomunikasi yang diperkenalkan oleh ETSI dan distandarkan oleh ITU-T G.107 [4]. Berikut rumus untuk memperoleh MOS secara objektif menggunakan persamaan (9).

$$
R=94.2-I_{d}-I_{e f}
$$

Yang mana :

$I_{d}=$ faktor dari penurunan kualitas suara oleh suatu delay.

$I_{e f}=$ faktor dari penurunan kualitas karena teknik kompresi dan packet loss.

$$
\begin{gathered}
I_{d}=0,024 d+0,11(d-177,3) \times H_{(d-177,3)} \\
I_{e f}=7+30 \ln (1+15 e)
\end{gathered}
$$

Yang mana :

$R=$ faktor kualitas pengiriman

$d=$ delay

$H=$ fungsi heavyside, yang mana:

$$
\begin{aligned}
& H_{(x)}=0, \text { if } x<0, \text { dan } \\
& H_{(x)}=1, \text { if } x \geq 0
\end{aligned}
$$

$e=$ persentase terjadi packet loss

Konversi nilai $\mathrm{R}$ ke MOS, berikut aturan yang harus digunakan:

- $\quad R<0 ; M O S=1$

- $\quad R>100 ; M O S=4,5$

- $0<R<100 ;$ MOS $=1+0,035 R+\left(7 \times 10^{-6}\right) R(R-60)(100-R)$

e. Nilai Mean Opinion Score

Mean Opinion Score (MOS) merupakan sebuah penilaian secara subjektif dalam mengukur kualitas suara yang direkomnedasikan oleh ITU-T pada tahun 1996. Nilai MOS diperoleh dengan menilai langsung kualitas suara yang didengar [6]. Berikut nilai MOS beserta kriteria kualitas dapat dilihat pada tabel berikut

TABEL I

NILAI KUALITAS MOS

\begin{tabular}{|c|c|}
\hline MOS & Kualitas \\
\hline 5 & $\begin{array}{c}\text { Sangat } \\
\text { Baik }\end{array}$ \\
\hline 4 & Baik \\
\hline 3 & Cukup \\
\hline 2 & Buruk \\
\hline 1 & $\begin{array}{c}\text { Sangat } \\
\text { Buruk }\end{array}$ \\
\hline
\end{tabular}

\section{EVALUASI SISTEM}


Siti A. Karimah et.al.

Pada evaluasi ini menjelaskan hasil yang didapat dari percobaan sesuai dengan skenario yang telah dipaparkan sebelumnya. Berikut hasil percobaan terhadap delay, throughput, packet loss, R-factor, dan Nilai Mean Opinion Score (MOS).

A. Performansi Drop Tail

TABEL II

PERFORMANSI DROP TAIL

\begin{tabular}{|c|c|c|c|c|c|}
\hline \multirow{2}{*}{$\begin{array}{c}\text { Traffic Shaping } \\
(\text { Kbps })\end{array}$} & \multirow{2}{*}{$\begin{array}{c}\text { Rata-Rata Delay } \\
(\mathrm{ms})\end{array}$} & \multirow{2}{*}{$\begin{array}{c}\text { Throughput } \\
(\mathrm{Mbit} / \mathrm{s})\end{array}$} & \multicolumn{3}{|c|}{ Dropped Packet } \\
\cline { 4 - 6 } & & & Receive & Expected & Loss \\
\hline 90 & 19.986686 & 0,168 & 11020 & 11020 & $0 \%$ \\
\hline 80 & 41.797767 & 0,112 & 8157 & 10996 & $25.82 \%$ \\
\hline 70 & 99.270147 & 0.08 & 4582 & 9297 & $50,72 \%$ \\
\hline
\end{tabular}

Pada tabel 2 menjelaskan peformansi Droptail pada setiap skenario bottleneck yaitu $90 \mathrm{Kbps}, 80 \mathrm{Kbps}, 70$ Kbps. Pada tabel 2 terlihat bahwa semakin kecil nilai traffic shaping maka semakin besar nilai rata-rata delay dan packet loss, sedangkan nilai throughput semakin kecil. Hal ini menjadi sangat wajar mengingat semakin kecil bandwidth yang tersedia, semakin tinggi pula latency yang akan dialami sebab jaringan menjadi lebih padat.

B. Performansi Proportional Integral Controller Enhanced (PIE)

TABEL III

PERFORMANSI PIE

\begin{tabular}{|c|c|c|c|c|c|}
\hline \multirow{2}{*}{$\begin{array}{c}\text { Traffic } \\
\text { shaping } \\
(\text { Kbps })\end{array}$} & Rata-Rata Delay $(\mathrm{ms})$ & \multirow{2}{*}{$\begin{array}{c}\text { Throughput } \\
(\mathrm{Mbit} / \mathrm{s})\end{array}$} & \multicolumn{3}{|c|}{ Dropped Packet } \\
\cline { 4 - 6 } & 19.994444 & & Receive & Expected & Loss \\
\hline 90 & 25.927081 & 0,168 & 11017 & 11017 & $0 \%$ \\
\hline 80 & 62.84687 & 0,096 & 4093 & 6786 & $39.68 \%$ \\
\hline 70 & & & 9529 & 10761 & $11.45 \%$ \\
\hline
\end{tabular}

Pada tabel 3 menjelaskan peformansi Proportional Integral Controller Enhanced (PIE) pada setiap skenario bottleneck yang diujikan. Pada table tersebut juga terlihat semakin kecil traffic shaping, semakin besar nila rata-rata delay dan packet loss, sedangkan nilai throughput semakin kecil.

C. Nilai Mean Opinion Score (MOS)

Pada tabel 4 menjelaskan tentang kualitas suara secara subjektif. Survei dilakukan terhadap 30 orang. Pemilihan 30 orang ini didasarkan pada referensi [14] yang menyebutkan bahwa 30 merupakan jumlah sample yang dapat mewakili dengan rentang usia responden berkisar antara 18 - 20 tahun dan memiliki pendengaran normal. 30 orang ini mendengarkan rekaman dari semua skenario (skenario dengan traffic shaping sebesar 90kbps, $80 \mathrm{kbps}$ dan $70 \mathrm{kbps}$ ) yang diujikan, lalu mengisi nilai antara $1-5$. Pada skenario 1 nilai MOS tidak terlalu signifikan, tetapi pada skenario 2 dan 3 mulai terlihat nilai yang cukup signifikan. 
TABEL IV

NILAI MOS

\begin{tabular}{|c|c|c|c|c|c|c|}
\hline \multirow[b]{2}{*}{ No } & \multicolumn{3}{|c|}{ PIE } & \multicolumn{3}{|c|}{ Droptail } \\
\hline & $\begin{array}{c}90 \\
\text { Kbps }\end{array}$ & $\begin{array}{c}80 \\
\text { Kbps }\end{array}$ & $\begin{array}{c}70 \\
\text { Kbps }\end{array}$ & $\begin{array}{c}90 \\
\text { Kbps }\end{array}$ & $\begin{array}{c}80 \\
\text { Kbps }\end{array}$ & $\begin{array}{c}70 \\
\text { Kbps }\end{array}$ \\
\hline 1 & 4 & 3.5 & 1.5 & 4 & 3 & 1 \\
\hline 2 & 4 & 3 & 3 & 4 & 2 & 2 \\
\hline 3 & 5 & 3 & 2 & 5 & 2 & 1.5 \\
\hline 4 & 5 & 3 & 2 & 4 & 2 & 1 \\
\hline 5 & 4 & 3 & 2 & 4 & 2 & 1 \\
\hline 6 & 4 & 3 & 2 & 4 & 2 & 2 \\
\hline 7 & 4 & 3 & 3 & 4 & 3 & 3 \\
\hline 8 & 5 & 3.5 & 2 & 4 & 3 & 1 \\
\hline 9 & 5 & 3 & 3 & 5 & 2 & 3 \\
\hline 10 & 5 & 4 & 2 & 4 & 2 & 2 \\
\hline 11 & 4 & 3 & 2 & 4 & 2 & 1 \\
\hline 12 & 5 & 3 & 1 & 5 & 3 & 1 \\
\hline 13 & 5 & 3 & 2 & 5 & 2 & 1.5 \\
\hline 14 & 4 & 3 & 3 & 4 & 2 & 2 \\
\hline 15 & 4 & 3 & 2 & 3 & 2 & 2 \\
\hline 16 & 5 & 3 & 2 & 4 & 3 & 2 \\
\hline 17 & 4 & 3 & 1 & 3 & 2 & 1 \\
\hline 18 & 3 & 2 & 1 & 3 & 2 & 1 \\
\hline 19 & 3.5 & 2.5 & 1 & 3 & 2 & 1 \\
\hline 20 & 4 & 3 & 2 & 3.5 & 2.5 & 1.5 \\
\hline 21 & 3.5 & 3 & 1.5 & 3 & 2.5 & 1 \\
\hline 22 & 3 & 2 & 1 & 3 & 2 & 1 \\
\hline 23 & 5 & 3 & 2 & 5 & 3 & 2 \\
\hline
\end{tabular}


Siti A. Karimah et.al.

Performansi Algoritma Proportional...

\begin{tabular}{|c|c|c|c|c|c|c|}
24 & 5 & 3 & 2 & 4 & 2 & 1 \\
\hline 25 & 5 & 3 & 1 & 5 & 3 & 1 \\
\hline 26 & 4 & 3 & 2 & 4 & 2 & 2 \\
\hline 27 & 5 & 4 & 2 & 4 & 2 & 2 \\
\hline 28 & 4.5 & 3 & 1.5 & 4 & 3 & 1 \\
\hline 29 & 5 & 3 & 2 & 5 & 2 & 1 \\
\hline 30 & 3 & 1.5 & 0.5 & 3 & 1 & 0.5 \\
\hline Mean & 4.317 & 2.967 & 1.833 & 3.983 & 2.267 & 1.467 \\
\hline
\end{tabular}

D. Nilai R-Factor

TABEL V

NILAI R-FACTOR

\begin{tabular}{|c|c|c|}
\hline \multirow{2}{*}{$\begin{array}{c}\text { Traffic } \\
\text { shaping } \\
\text { (Kbps) }\end{array}$} & \multicolumn{2}{|c|}{ R-Factor } \\
\cline { 2 - 3 } & PIE & Droptail \\
\hline 90 & 86.720 & 86.720 \\
\hline 80 & 56.586 & 38.686 \\
\hline 70 & 27.521 & 20.237 \\
\hline
\end{tabular}

Pada tabel 5 menjelaskan tentang nilai dari R-Factor dari semua skenario yang diujikan. Sama seperti nilai Mean Opinion Score (MOS), perbedaan yang signifikan terlihat pada skenario 2 dan 3.

E. Perbandingan Drop Tail dan PIE

a) Delay 


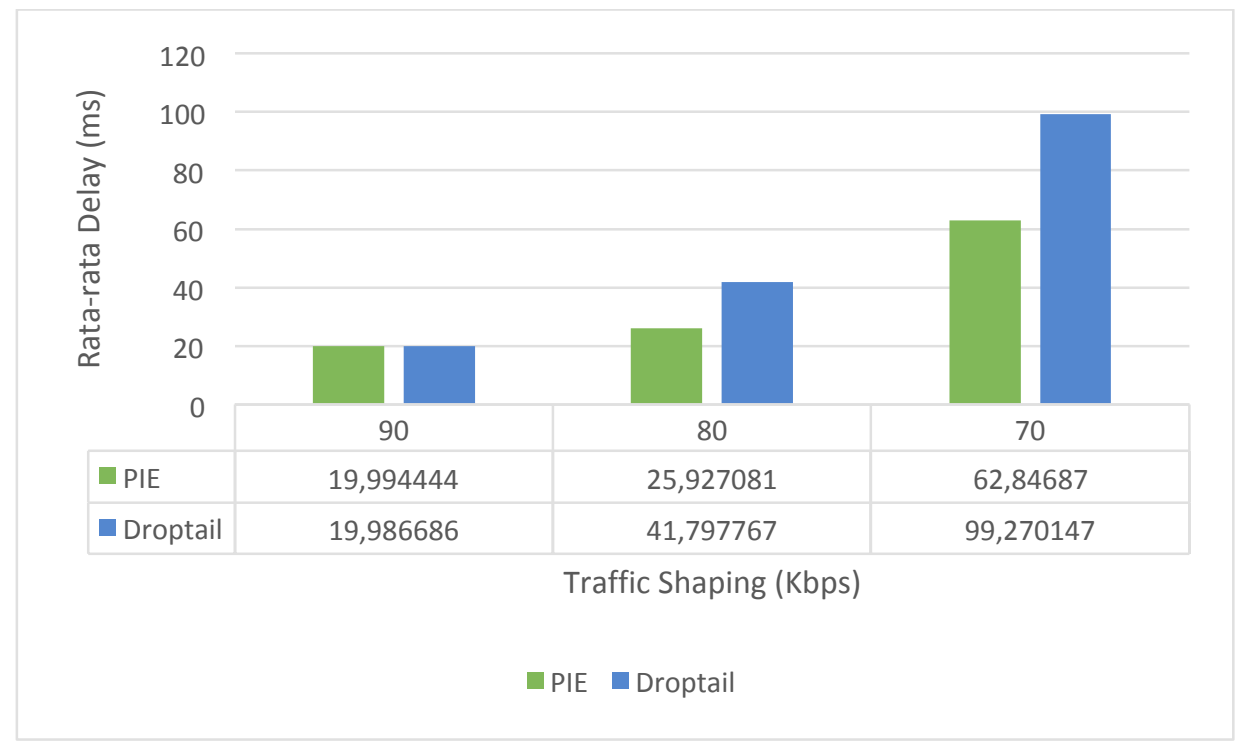

GAMBAR 3. RATA-RATA DELAY PIE DAN,DROPTAIL

Gambar 3 menjelaskan bahwa pada skenario 1 (90 Kbps) perbedaan delay tidak terlalu signifikan, akan tetapi pada skenario 2 (80 Kbps) dan skenario 3 (70 Kbps) perbedaan delay mulai terasa. Hal ini dikarenakan paket RTP sangat kecil yaitu $85 \mathrm{Kbps}$ sehingga pada skenario 1 tidak terasa perbedaannya. Pada skenario 2 dan skenario 3 algoritma PIE menjaga delay agar tetap rendah. Hal ini disebabkan karena algoritma PIE menjaga latency tetap rendah dengan cara menggunakan timestamp untuk menandai setiap paket dalam antrian. Ketikan paket melebihi timestamp, maka paket tersebut akan di-drop untuk menjaga antrian tidak penuh dan menjaga delay tetap rendah.

\section{b) Throughput}

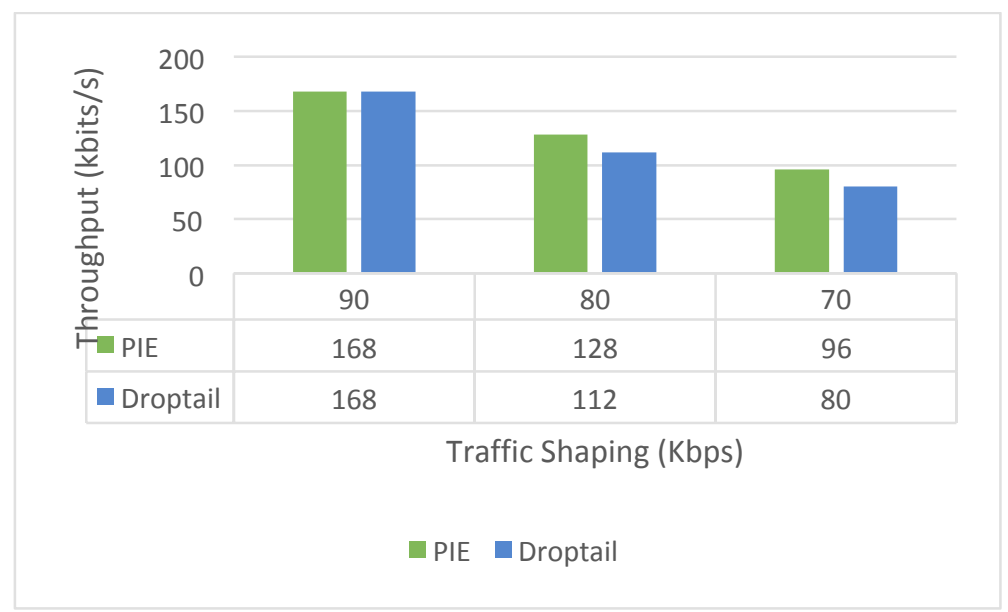

GAMBAR 4. THROUGHPUT PIE DAN DROPTAIL

Gambar 4 menjelaskan peformansi kedua algoritma dalam menangani throughput, algoritma PIE lebih besar daripada droptail. Pada setiap skenario memiliki nilai throughput yang berbeda, hal ini dikarenakan 
Siti A. Karimah et.al.

Performansi Algoritma Proportional...

bandwidth yang diberikan. Jadi semakin besar bandwidth maka throughput juga akan semakin besar. Perbedaan throughput antara kedua antara PIE dan Droptail tidak terlalu signifikan karena RTP yang sangat kecil. Nilai throughput pada PIE lebih bagus karena PIE menjaga latency tetap rendah pada router.

\section{c) Packet Loss}

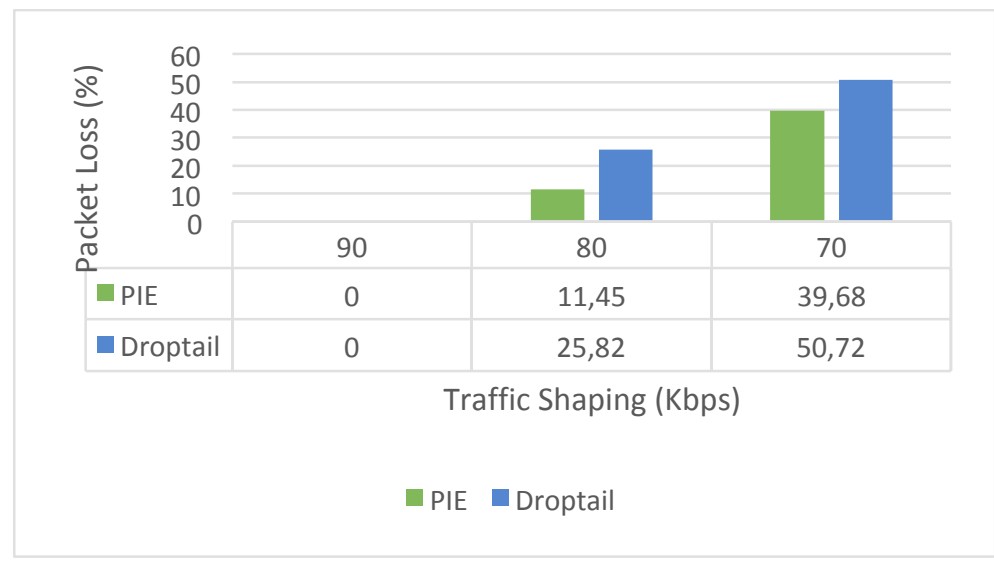

GAMBAR 5. PACKET LOSS PIE DAN DROPTAIL

Gambar 5 menjelaskan tentang perbandingan packet loss pada setiap scenario yang diujikan. Pada skenario 1 tidak terjadi packet loss karena kecilnya paket RTP itu sendiri, sehingga paket langsung diantarkan dari client 1 ke client 2. Packet loss mulai terjadi pada skenario 2 (80 Kbps) dan skenario 3 (70 Kbps) karena data mulai terjadi congestion pada router disebabkan bandwidth yang disediakan sangat kecil. Algoritma PIE menangani packetloss lebih baik karena PIE memiliki hitungan Drop Probability dengan menjaga latency tetap rendah dan menjaga antrian dalam router tetap stabil. sedangkan algoritma Droptail akan membuang (drop) semua paket apabila antrian dalam router penuh.

\section{d) Nilai Mean Opinion Score (MOS)}

Terdapat dua macam nilai Mean Opinion Score (MOS) pada penelitian ini,yaitu secara subjektif dan objektif. Secara subjektif nilai langsung diberikan setelah mendengar semua skenario dimana pada penelitian ini nilai diambil dari rata-rata nilai yang diberikan oleh 30 orang. Secara Objektif nilai MOS diambil dari nilai R-Faktor.

\section{- Subjektif}




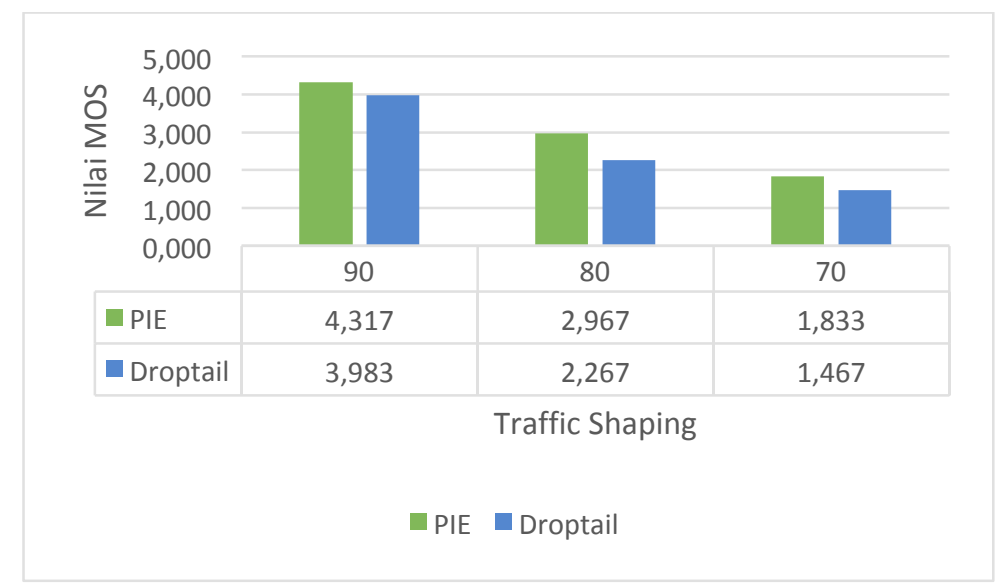

GAMBAR 6. MOS SUBJEKTIF PIE DAN DROPTAIL

Pada gambar 6 terlihat jelas perbedaan nilai MOS antara PIE dan Droptail. Hasil ini diambil dari rata-rata total nilai dari penilaian dari 30 orang yang mendengarkan langsung rekaman call VoIP pada setiap skenario. Algoritma PIE mendapatkan nilai MOS lebih baik daripada Droptail, hal ini juga mengacu dari hasil parameter delay, throughput, dan juga packetloss dimana PIE lebih baik daripada Droptail. Jadi semakin bagus penanganan throughput, delay, dan packetloss maka semakin bagus juga kualitas yang dihasilkan.

\section{- Objektif}

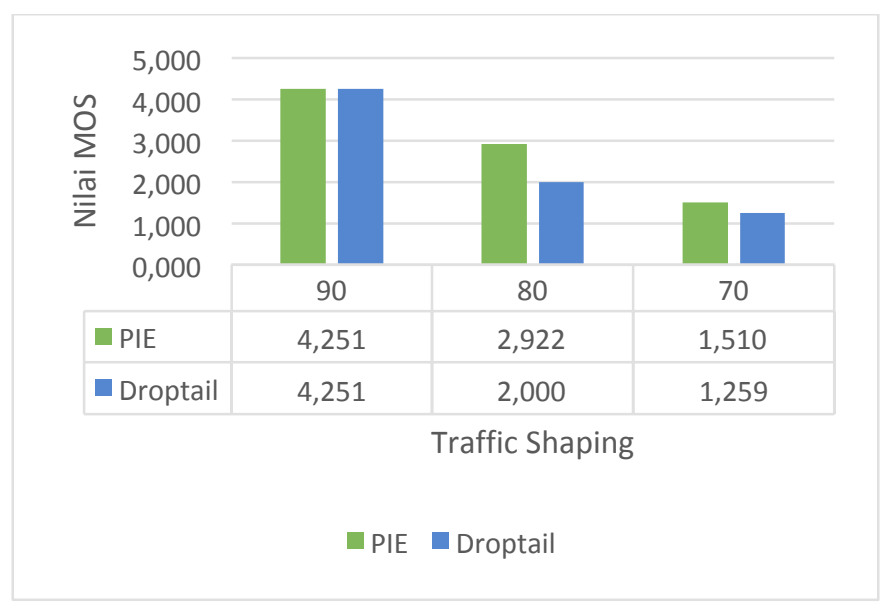

GAMBAR 7. MOS OBJEKTIF PIE DAN DROPTAIL

Pada gambar 7 merupakan nilai Mean Opinion Score (MOS) yang didapatkan dari nilai $R$-factor yang dapat dilihat pada tabel 5. Dapat dilihat secara objektif nilai PIE juga lebih baik daripada Droptail sesuai dengan nilai subjektif yang didapatkan seperti gambar 5. Nilai yang didapatkan juga tidak jauh berbeda. Hal ini membuktikan bahwa dalam memaksimalkan kualitas layanan VoIP, menggunakan algoritma PIE lebih baik daripada Droptail. 
Siti A. Karimah et.al.

\section{KESIMPULAN}

Tujuan penelitian ini adalah untuk menguji kualitas MOS pada algoritma Proportional Integral Controller Enhanced (PIE) dan Droptail pada jaringan Voice over Internet Protocol (VoIP). Hasil perbandingan antara dua algoritma tersebut telah di sajikan pada sub bab 4.5. Dari hasil pengujian terlihat bahwa semakin kecil traffic shaping yang diimplementasikan, semakin turun performansinya, baik diliihat dari MOS secara subjektif dan objektif, throughput, packet loss maupun delay. Pada skenario traffic shaping 90 Kbps, perbedaan kualitas layanan VoIP baik menggunakan algoritma PIE maupun Drop Tail memiliki kualitas yang setara. Namun ketika dilakukan traffic shaping $80 \mathrm{Kbps}$ dan $70 \mathrm{Kbps}$ terlihat bahwa kualitas layanan PIE mengungguli Drop Tail. Pada kasus terburuk, yakni ketika dilakukan traffic shaping sebesar 70Kbps, terlihat jelas bahwa perbandingan PIE memiliki nilai MOS yang lebih besar 30\% secara subjektif dan lebih besar 20\% secara objektif. Baiknya nilai MOS yang dihasilkan algoritma PIE disebabkan oleh sistem random droping yang membuang paket secara acak sehingga kualitas suara lebih jelas, sedangkan Droptail akan membuang semua paket apabila antrian sudah penuh.

\section{DAFTAR PUSTAKA}

[1] Z.Nasution. (2014). http://repository.ut.ac.id. Retrieved from http://repository.ut.ac.id: http://repository.ut.ac.id/4482/2/SKOM4322TM.pdf

[2] Satria Mandala, M. N. (2017, Maret 1). Actove Queue Management (AQM) Performance Analysis based on Controled Delay (CoDel) Algorithm on UDP. Indonesian Journal of Computing, 2, 1. doi:10

[3] A Nur Lina, 2014, Congestion (pada jarigan data), (online) http://nurlinaamik.blogspot.co.id/2014/06/congestion-pada-jaringandata.html. Diakses : 10 November 2017.

[4] La Surimi, R. P. (2015, July). Analisis Kualitas VoIP pada SCTP Menggunakan ECN dan AQM. Indonesian Journal of Computing and Cybernetics Systems, 9, 123.

[5] Alilied Telesis “QOS White Paper”. https://www.alliedtelesis.com/documents/qos-white-paper. Diakses : 12 November 2017.

[6] Ginanjar Rahmansyah, T. B. (2015). Analisis Mekanisme Active Queue Management (AQM) Berbasis Controlled Delay., II, p. 1145. Bandung. Retrieved 8 14, 2018

[7] ITU-T Series G. 2003. "Transmission system and media, Digital systems and networks".

[8] Andrew, 2011, "Difference Between R-Factor and MOS Score in VoIP Quality". http://www.differencebetween.com/differencebetween-r-factor-and-mos-score-in-voip-quality/. Diakses : 12 November 2017.

[9] International Conference on High Performance Switching and Routing (pp. 148-155). Taipei: IEEE. doi:10.1109/HPSR.2013.6602305

[10] ISKANDAR, M. N. (2017). ANALISIS PERFORMANSI ACTIVE QUEUE MANAGEMENT (AQM) BERBASIS ALGORITMA CONTROL DELAY (CoDel) PADA STREAMING USER DATAGRAM PROTOCOL (UDP). (S. M. MUH. ARIF NUGROHO, Ed.) Bandung, Indonesia: Telkom.

[11] Nobuhiko Kitawaki, A. T. (2004, July 28). Perceptual QoS Assessment. erceptual QoS assessment technologies for VoIP, 28 - 34. doi:10.1109/MCOM.2004.1316526

[12] Setiawan, E. B. (2012, October). ANALISA QUALITY OF SERVICES (QoS) VOICE OVER INTERNET PROTOCOL (VoIP) DENGAN PROTOKOL H.323 DAN SESSION INITIAL PROTOCOL (SIP). ANALISA QUALITY OF SERVICES (QOS) VOICE OVER INTERNET PROTOCOL (VOIP) DENGAN PROTOKOL H.323 DAN SESSION INITIAL PROTOCOL (SIP), 7 - 8. Retrieved from https://ojs.unikom.ac.id/

[13] Misbahul, F. (2016, November). Simulasi Antrian Paket Data Jaringan dengan Mekanisme Drop Tail. Jurnal Ilmiah FIFO, VIII, 151 - 160. Retrieved 1110,2017

[14] Hogg and Tanis.2013.Probability and Statistical Inference (9e). USA :Pearson. 